\title{
Procalcitonin as a prognostic biomarker of severe sepsis and septic shock
}

\author{
Procalcitonina como biomarcador de prognóstico da sepse grave e choque \\ séptico
}

José Raimundo Araujo de Azevedo'; Orlando Jorge Martins Torres, TCBC-MA²; Nicolau Gregori CZeczko, TCBC-PR; Felipe Francisco Tuon 3 ; Paulo Afonso Nunes Nassif, TCBC-PR³; Gleim Dias de Souza4

A B S T R A C T

\begin{abstract}
Objective: To evaluate the tendency of the plasma concentration and clearance of procalcitonin (PCT-C) as biomarkers of prognosis of patients with severe sepsis and septic shock, compared to another early prognosis marker, the number of SIRS criteria at sepsis diagnosis. Methods: We conducted a prospective, observational, cohort study, with patients with severe sepsis and septic shock. The serum procalcitonin was determined at diagnosis of sepsis and after 24 and 48 hours. Demographic data, APACHE IV, SOFA score on arrival, number of SIRS criteria at diagnosis, site of infection and microbiological results were recorded. Results: Twenty-eight patients were included, 19 clinical and nine surgical. In $13(46.4 \%)$ the source of sepsis was pulmonary, abdominal in seven (25.0\%), urinary in five $(17.9 \%)$ and soft tissue in three cases (10.7\%). Fifteen patients had severe sepsis and 13 septic shock. Overall mortality was $17.9 \%$ (five patients), three with septic shock. Twentyeight PCT determinations were performed at sepsis diagnosis, 27 after 24 hours and 26 after 48 hours. The initial concentration was not significantly different between survivors and non-survivors groups, but the differences between the two groups after 24 and 48 hours were statistically significant. There was no difference in the number of SIRS criteria. The 24-hour procalcitonin clearance proved to be significantly higher in the group of survivors (-3.0 versus $-300.0, p=0.028$ ). Although the 48-hour procalcitonin clearance has shown to be higher in the group of survivors when compared to nonsurvivors, the difference did not reach statistical significance. Conclusion: Persistently high procalcitonin concentrations in plasma, as well as reduced 24-hours PCT clearence, were associated with a significant increase in mortality in patients with severe sepsis and septic shock.
\end{abstract}

Key words: Patients. Prognosis. Sepsis. Septic shock. Biological markers.

\section{INTRODUCTION}

Proston ocalcitonin (PCT), the precursor peptide of calcitonin, a hormone involved in calcium homeostasis, is present in normal subjects in extremely low serum levels (0.1 to $0.5 \mathrm{ng} / \mathrm{ml}$ ). In response to bacterial infectious stimulation serum procalcitonin rises substantially and its role in inflammatory response includes chemotactic function, modulation of inducible nitric oxide synthase and induction of cytokines, among other ${ }^{1-5}$.

Several studies have shown that the measurement of procalcitonin is highly sensitive and specific for distinguishing SIRS (systemic inflammatory response syndrome $)^{6}$ from sepsis, bacterial pneumonia of other inflammatory lung conditions ${ }^{7}$ and pancreatic necrosis from septic pancreas necrosis ${ }^{8}$. Serial PCT assessments have been used to determine the time of treatment of pneumonia and other infections ${ }^{9}$.

More recently, PCT has been used as a biomarker of prognosis. In severe sepsis and septic shock isolated determinations of serum PCT have shown variable results ${ }^{10-15}$. Most studies say that it is not possible to predict the outcome of critically ill patients based on high levels of $P C T$. Encouraging results were obtained from studies involving small numbers of patients and showed that serial determinations of PTC correlated with prognosis ${ }^{12,13}$.

In recent studies, Guan et al. ${ }^{16}$ and Ruiz-Rodriguez et al. ${ }^{17}$ suggested, by analyzing small case series, that dynamic changes of PCT could be predictive of outcome in patients with severe sepsis and septic shock.

The identification of a prognostic marker that may predict the outcome at the end of 24 to 48 hours of

Work done at the Intensive Care Unit, Santo Domingo Hospital, São Luis, Maranhão State - MA, and at the Post-Graduation Program in Principles of Surgery, Faculdade Evangélica do Paraná / Hospital Evangélico de Curitiba, Curitiba, Paraná State - PR, Brazil.

1. Coordinator, Intensive Care Unit, São Domingos Hospital; 2. Surgeon, Department of Surgery, São Domingos Hospital; 3. Permanent Professor, Post-Graduation Program in Principles of Surgery, Medical Research Institute, Evangelical Faculty of Paraná; 4. PhD, Post-Graduation Program in Principles of Surgery, Medical Research Institute, Evangelical Faculty of Paraná / Evangelical Hospital of Curitiba, Curitiba, PR, Brazil. 
treatment of severe sepsis and septic shock could be very useful in order to provide a reassessment of the patient, identifying perpetuators of gravity, permitting interventions and conduct reorientation. The addition of this marker for the routine evaluation of patients with severe sepsis and septic shock treated according to the Surviving Sepsis Campaign ${ }^{18}$ strategies might bring additional contribution towards reducing morbidity and mortality.

Some studies have attempted to establish the relationship between the intensity of the systemic inflammatory response and outcome of sepsis and septic shock. Rangel-Frausto et al. ${ }^{19}$ analyzed more than 2500 patients with SIRS of infectious cause and found a significant correlation between severity of SIRS translated by the number of positive criteria and mortality. Sprung et al. ${ }^{20}$, in a study that included more than 3000 patients from 198 ICUs of 24 European countries, showed that the presence of more than two SIRS criteria in infected patients was associated with increased risk of developing severe sepsis and septic shock, and was also associated with significantly increased mortality. In conclusion, the authors suggested that the criteria for SIRS, which are easy to measure, should be compared with other markers for diagnosis and prognosis of sepsis in future studies.

The analysis of dynamic changes of procalcitonin can predict the outcome and provide early interventions to change the course of patients with severe sepsis and septic shock.

The aim of this study was to evaluate the usefulness of procalcitonin (PCT-C) as a biomarker of prognosis of patients with severe sepsis and septic shock through trend analysis of plasma concentration and clearance of PCT in the first 24 and 48 hours of treatment, comparing to another early marker of prognosis, the number of SIRS criteria at sepsis diagnosis.

\section{METHODS}

This was a cohort, prospective and observational study, whose project was approved by the Research Ethics Committee of the São Domingo Hospital, São Luís, MA on 16/4/12 under number 009/2012.

The study included 28 patients admitted to a general ICU of 37 beds in a tertiary hospital in São Luis, Maranhão State, in the period between May 1 and September 30, 2012.

Inclusion criteria were: patients aged 18 years or more, not pregnant, that met criteria for severe sepsis or septic shock from the American College of Chest Physicians / Society of Critical Care Medicine ${ }^{21}$, ie, sepsis associated with at least one organ dysfunction and / or signs of tissue hypoperfusion unresponsive to intravenous administration of $20 \mathrm{ml} / \mathrm{kg}$ of fluid, requiring infusion of vasoactive drugs.

All patients were treated according to the institutional protocol for management of severe sepsis and septic shock, based on recommendations from the Surviving Sepsis Campaign, modified to meet recent evidence from the literature 22,23

The form of data collection included demographics, length of stay, outcome, patient clinical or surgical APACHE IV, death risk, SOFA score on arrival, number of SIRS criteria at diagnosis, site of infection, cultures (including results of blood cultures taken in the first hour), bacterial isolates, checklist package of six hours, use of corticosteroids for septic shock, use of protective ventilation, blood glucose control, blood glucose average in the first 24 hours and PCT clearance of 24 and 48 hours .

Dosages of procalcitonin in serum were performed at diagnosis of sepsis and repeated at the end of the first 24 and 48 hours of treatment beginning. The determinations were carried out by the technique of electrochemiluminescence (ECLIA). The reagent used in these assays was developed in collaboration with Brahms Diagnostica, Berlin, Germany.

The procalcitonin clearance (PCT-C) was calculated using the formula: initial PCT less than PCT of 24 and 48 hours, divided by the initial and PCT, then multiplied by 100 .

Results were expressed as mean \pm standard deviation, median with interquartile ranges or proportions. Comparisons between categorical variables were performed with Fisher's exact and chi-square tests, and between continuous variables with Student's t or Mann-Whitney U. tests

To calculate the sample size we used results of study comparing PTC-c between survivors and non-survivors, analyzing population of patients with septic shock ${ }^{17}$. We reached $n=28$ by using the two-samples ratio test (test power of 0.8 and alpha level of 0.05 ).

\section{RESULTS}

Twenty-eight patients were included. Table 1 shows the characteristics of the study population. Nineteen patients were clinical, nine surgical; in 13 patients (46.4\%) the source of sepsis was pulmonary, abdominal in seven patients (25.0\%), urinary infection in five (17.9\%) and soft tissue in three cases (10.7\%). Fifteen patients had severe sepsis and septic shock ${ }^{13}$. Overall mortality was five patients $(17.9 \%)$, three with septic shock.

Twenty-eight PCT determinations were performed at diagnosis of sepsis, 27 after 24 hours and 26 after 48 hours. The initial median concentration of 24 hours and 48 hours is shown in Table 2. The initial concentration was not significantly different between survivors' and nonsurvivors' groups, but the differences between the two groups after 24 and 48 hours were expressively statistically significant. There was no difference in the number of SIRS criteria. The 24-hour procalcitonin clearance proved to be significantly higher in the survivors' group ( 3.0 versus - 
300.0, $p=0.028$ ). Although the 48-hour procalcitonin clearance has shown higher results in the survivors' group when compared to the non-survivors', the difference did not reach statistical significance.

\section{DISCUSSION}

This study corroborates the results of previous analyzes shoing that dynamic changes of procalcitonin, translated by plasma concentrations and clearance after 24 and 48 hours, are effective biomarkers for prognosis of severe sepsis and septic shock. This study failed to demonstrate efficiency of the number of SIRS criteria identified in the initial assessment of the patient to distinguish survivors from non-survivors.

Sepsis and its complications represent the main cause of death in intensive care units. Although initiatives such as the Surviving Sepsis Campaign have brought substantial improvement to patient survival, they do not incorporate indicators that can identify patients with early unfavorable prognosis. This would allow reassessments of patients regarding diagnosis of complications and need for changes in treatment that could, in time, reverse the unfavorable course.
Several prognostic indices are now used in intensive care units. The two most widely in use and are validated APACHE (Acute Physiology and Chronic Health Evaluation) and SAPS (Simplified Acute Physiology Score), which, however, have limited their utility to the first 24 hours of treatment and do not offer the possibility to inform about the progress of patients in response to the first few hours of treatment. The SOFA score (Sequential Organ Failure Assessment), which assesses organ dysfunction, has been proposed as a prognostic score of evolutionary value, and several studies have shown that, for example, the delta SOFA (72-hour SOFA minus admission SOFA) can separate survivors from no survivors with enough accuracy ${ }^{24,25}$. Nonetheless, SOFA as an assessment of organ dysfunction, which typically have several phases including periods of little or no clinical and laboratory manifestations, may depend on an excessively long time to identify an unfavorable progression, thereby undermining the possibility of early identification of adverse developments.

From the definitions of SIRS and sepsis by consensus conferences, several studies have tried to establish the relationship between inflammatory response and progression of sepsis to severe sepsis (sepsis associated with organ dysfunction) and septic shock (sepsis complicated by

Table 1 - Characteristics of the study population $(n=28)$.

\begin{tabular}{lrr}
\hline & $\mathbf{n}$ & $(\%)$ \\
\hline Women & 12 & $(42.8)$ \\
Clinical / Surgical & $19 / 9$ & \\
APACHE IV. mean (SD) & 74.9 & $(34.7)$ \\
Number of SIRS criteria. mean (SD) & 2.7 & $(0.7)$ \\
Number of organ dysfunctions. mean (SD) & 2.5 & $(0.9)$ \\
Site of sepsis & & \\
lung & 13 & $(46.4)$ \\
abdomen & 7 & $(25.0)$ \\
urinary & 5 & $(17.9)$ \\
Soft tissue & 3 & $(10.7)$ \\
Severe sepsis / septic shock. n & $13 / 15$ & \\
ICU mortality. $n$ (\%) & 5 & $(17.9)$ \\
\hline
\end{tabular}

Table 2 - $\quad$ PCT results in survivors and non-survivors $(n=28)$.

\begin{tabular}{lrrrrr}
\hline & \multicolumn{2}{c}{ Survivors $\mathbf{n}=\mathbf{2 3}$} & \multicolumn{1}{c}{ Non-Survivors $\mathbf{n}=\mathbf{5}$} & $\mathrm{p}$ value \\
\hline Number of SIRS criteria. mean (SD) & 2.77 & $(0.75)$ & 2.60 & $(0.54)$ & 0.63 \\
PCT i. median (IIQ) & 8.8 & $(2.1-12.7)$ & 10.8 & $(2.2-55.0)$ & 0.41 \\
PCT 24 h. median (IIQ) & 8.2 & $(3.4-14.8)$ & 68.6 & $(15.8-82.3)$ & 0.003 \\
PCT 48 h. median (IIQ) & 4.6 & $(2.4-9.4)$ & 31.0 & $(16.2-83.9)$ & 0.003 \\
PCT-c 24 h. median (IIQ) & -3.0 & $(-371.0-32.5)$ & -300.0 & $(-1.080 .0-48.0)$ & 0.028 \\
PCT-c 48 h Mediana (IIQ) & -0.0 & $(-158.0-58.5)$ & -290.0 & $(-1.175 .0-13.5)$ & 0.10 \\
\hline
\end{tabular}

PCTi, PCT $24 \mathrm{~h}, P C T 48 \mathrm{~h}=$ Initial, 24-hour and 48-hour concentrations of procalcitonin $(\mathrm{ng} / \mathrm{ml})$, respectively.

PCT-c 24h, PCT-c $48 \mathrm{~h}=$ Procalcitonin clearance at 24 and 48 hours (\%) 
hemodynamic instability) and their impact on mortality Rangel-Frausto et al. ${ }^{19}$ analyzed more than 2500 patients with SIRS of infectious cause and found a significant correlation between severity of SIRS translated by the number of positive criteria and mortality. Patients with four SIRS criteria had twice the mortality rate of those who had three criteria, and the latter, on their turn, displayed mortality $50 \%$ higher than those with only two SIRS criteria. Sprung et al. ${ }^{20}$, in a study that included more than 3000 patients from 198 ICUs of 24 European countries, showed that the presence of more than two SIRS criteria in infected patients was associated with increased risk of subsequent development of severe sepsis and septic shock and was also associated with significantly increased mortality. The authors conclude by suggesting that the criteria for SIRS, which are easy to measure, should be compared in future studies with other markers for diagnosis and prognosis of sepsis.

Procalcitonin has been proposed as a biomarker specific for bacterial infections. In normal individuals its concentrations are very low or undetectable ( 0.1 to $0.5 \mathrm{ng} /$ $\mathrm{ml})$. In the situation of colonization and viral infections its levels remain below $2 \mathrm{ng} / \mathrm{ml}$. In sepsis levels are generally above $3 \mathrm{ng} / \mathrm{mL}$ and may reach more than $100 \mathrm{ng} / \mathrm{ml}$ in septic shock.

More recently, PCT has been used as a biomarker of prognosis. In severe sepsis and septic shock, isolated determinations of serum PCT have shown variable results ${ }^{10,11}$. Most studies consider it not possible to predict the outcome of critically ill patients based on high levels of PCT. On the other hand, the evaluation of serial PCT values proved to be more useful in assessing prognosis. In patients with pulmonary sepsis, reductions in $\mathrm{PCT}$ concentration above 30\% between the second and third day of were identified as determinants of survival, with odds ratio of $2.9^{26}$. In patients with community-acquired pneumonia with decreased PCT from day one to day three, it was related to survival with $89 \%$ specificity, $82 \%$ negative predictive value and $71 \%$ positive predictive value ${ }^{25}$. Karlsson et al. ${ }^{12}$ showed in a recent study that mortality in patients with severe sepsis is smaller than in those whose PCT concentrations decreased by over $50 \%$ when compared to initial values. Claeys et al. ${ }^{13}$, analyzing patients with septic shock, showed that after 48 hours of admission, PCT levels only decreased substantially in the surviving. Guan et al. ${ }^{16}$ prospectively analyzed 37 patients with septic shock and showed that all survivors had lower levels of PCT during ICU stay and all non-survivors showed progressive elevation of PCT levels. Recently, Suberviola et al. ${ }^{26}$ and Ruiz-Rodriguez et al. ${ }^{17}$ introduced the concept of procalcitonin clearance in order to assess the evolutionary behavior of PCT and its relationship with mortality. In both studies the clearance of PCT was determined by the formula: (initial value - final value) / initial value $X 100$. Suberviola et al. ${ }^{26}$ studied 88 patients with septic shock admitted to a general ICU. The study showed that the mortality in patients with increased clearance of PCT in the first 72 hours of treatment was significantly lower than in patients with reduced clearance in the same period $(15.4 \%$ versus $58.8 \%, p<0.01$ ). RuizRodriguez et al. ${ }^{17}$ determined the clearance of PCT after 24,48 and 72 hours of treatment of 27 patients with septic shock and showed a significant increase in PCT clearance in survivors and reduction in non-survivors.

This study has limitations. The most important of these is the small sample size that limits the required rigorous statistical analysis. However, it stimulates analysis with larger samples and comparison of procalcitonin clearance with other markers of outcomes, such as delta SOFA.

In conclusion, persistently elevated concentrations of plasma procalcitonin in patients with severe sepsis and septic shock are associated with significantly higher mortality. The prognosis of severe sepsis and septic shock can be evaluated by 24-hour PCT clearance.

\section{R E S U M O}

Objetivo: Avaliar a tendência da concentração plasmática e do clearance de procalcitonina (PCT-c) como biomarcadores de prognóstico de pacientes com sepse grave e choque séptico, comparado a um outro marcador precoce de prognóstico representado pelo número de critérios de SIRS no momento do diagnóstico da sepse. Métodos: Estudo de coorte prospectivo observacional onde foram incluídos pacientes com sepse grave e choque séptico. A concentração sérica de procalcitonina foi determinada no momento do diagnóstico da sepse e após 24 e 48 horas. Foram coletados dados demográficos, escore APACHE IV, escore SOFA na chegada, número de critérios de SIRS no momento do diagnóstico, sitio da infecção e resultados microbiológicos. Resultados: Vinte e oito pacientes foram incluídos, 19 clínicos e nove cirúrgicos. Em 13 (46,4\%) a fonte da sepse foi pulmonar, em sete abdominal (25,0\%), em cinco urinária $(17,9 \%)$ e de partes moles em três casos (10,7\%). Quinze pacientes tinham sepse grave e 13 choque séptico. A mortalidade global foi cinco pacientes (17,9\%), três deles com choque séptico. Vinte e oito determinações de PCT foram realizadas no momento do diagnóstico da sepse, 27 após 24 horas e 26 após 48 horas. A concentração inicial não se mostrou expressivamente diferente entre os grupos sobreviventes e não sobreviventes, mas as diferenças entre os dois grupos após 24 e 48 horas alcançaram significância estatística expressiva. Não se observou diferença em relação ao número de critérios de SIRS. O clearance de procalcitonina de 24 horas mostrouse expressivamente mais elevado no grupo de sobreviventes $(-3,0$ versus $-300,0, p=0,028)$. Embora o clearance de procalcitonina de 48 horas tenha mostrado resultado mais elevado no grupo de sobreviventes comparado aos não sobreviventes, a diferença não alcançou significância estatística. Conclusão: Concentrações persistentemente elevadas de procalcitonina no plasma, assim como, redução do PCT-c 24 horas, associaram-se à elevação expressiva da mortalidade de pacientes com sepse grave e choque séptico.

Descritores: Pacientes. Prognóstico. Sepse. Choque séptico. Marcadores biológicos. 


\section{REFERENCES}

1. Sexton PM, Christopoulos G, Christopoulos A, Nylen ES, Snider RH Jr, Becker KL. Procalcitonin has bioactivity at calcitonin receptor family complexes: potential mediator implications in sepsis. Crit Care Med. 2008;36(5):1637-40.

2. Hoffmann G, Totzke G, Seibel M, Smolny M, Wiedermann FJ, Schobersberger $\mathrm{W}$. In vitro modulation of inducible nitric oxide synthase gene expression and nitric oxide synthesis by procalcitonin. Crit Care Med. 2001;29(1):112-6.

3. Macedo JLS, Rosa SC, Macedo KCS, Castro C. Fatores de risco da sepse em pacientes queimados. Rev Col Bras Cir. 2005;32(4):1737.

4. Macri MM, Matias JEF, Souza CJF, Nicoluzzi JEL, Caron PE, Repka $J C D$. Influência do pneumoperitônio nas funções hepática e renal e na liberação de citocinas pró-inflamatórias em modelo experimental de endotoxemia induzida por lipopolissacarídeo de Escherichia coli. ABCD arq bras cir dig. 2009;22(4):206-11.

5. Lima JBA. Skare TL, Malafaia O, Ribas-Filho JM, Michaelis T, Ribas FM, et al. Síndrome de disfunção de múltiplos órgãos induzida por sepse: estudo experimental em ratos. $A B C D$ arq bras cir dig. 2011;24(2): 95-102.

6. Tang BM, Eslick GD, Craig JC, McLean AS. Accuracy of procalcitonin for sepsis diagnosis in critically ill patients: systematic review and meta-analysis. Lancet Infect Dis. 2007;7(3):210-7.

7. Ramirez P, Garcia MA, Ferrer M, Aznar J, Valencia M, Sahuquillo $J M$, et al. Sequential measurements of procalcitonin levels in diagnosis of ventilator-associated pneumonia. Eur Respir J. 2008;31(2):356-62.

8. Rau BM, Kemppainen EA, Gumbs AA, Büchler MW, Wegscheider $K$, Bassi $C$, et al. Early assessment of pancreatic infections and overall prognosis in severe acute pancreatitis by procalcitonin (PCT): a prospective international multicenter study. Ann Surg. 2007;245(5):745-54.

9. Briel M, Schuetz P, Mueller B, Young J, Schild U, Nusbaumer C, et al. Procalcitonin-guided antibiotic use vs a standard approach for acute respiratory tract infection in primary care. Arch Intern Med. 2008;168(18):2000-7

10. Meng FS, Su L, Tang YQ, Wen Q, Liu YS, Liu ZF. Serum procalcitonin at the time of admission to the ICU as a predictor of short-term mortality. Clin Biochem. 2009;42(10-11):1025-31.

11. Jensen JU, Heslet $L$, Jensen $T H$, Espersen $K$, Steffensen P, Tvede $M$. Procalcitonin increase in early identification of critically ill patients at high risk of mortality. Crit Care Med. 2006;34(10):2596602.

12. Karlsson S, Heikkinen $M$, Pettilä V, Alila S, Väisänen S, Pulkki K, et al. Predictive value of procalcitonin decrease in patients with severe sepsis: a prospective observational study. Crit Care. 2010;14(6):R205.

13. Claeys R, Vinken S, Spapen H, ver Elst K, Decochez K, Huyghens L, et al. Plasma procalcitonin and $\mathrm{C}$-reactive protein in acute septic shock: clinical and biological correlates. Crit Care Med. 2002;30(4):757-62.

14. Velho AV, Mello LF, Oliveira Filho T, Dacanal FM, Ostermann RAB. Fatores preditivos de infecção no trauma de cólon. Rev Col Bras Cir. 2000;27(3):155-61

15. Rocha SL, Souza GRMR, Abujamra KB, Ostrowski MAB, Souza MCMR. Gasometria arterial e inflamação pulmonar de ratos com diferentes tempos de sepse abdominal. $A B C D$ arq bras cir dig. 2007;20(1):28-33
16. Guan J, Lin Z, Lue H. Dynamic change of procalcitonin, rather than concentration itself, is predictive of survival in septic shock patients when beyond $10 \mathrm{ng} / \mathrm{ml}$. Shock. 2011;36(6):570-4.

17. Ruiz-Rodríguez JC, Caballero J, Ruiz-Sanmartin A, Ribas VJ, Pérez $M$, Bóveda JL, et al. Usefulness of procalcitonin clearance as a prognostic biomarker in septic shock. A prospective pilot study. Med Intensiva. 2012;36(7):475-80

18. Dellinger RP, Levy MM, Carlet JM, Bion J, Parker MM, Jaeschke R, et al. Surviving Sepsis Campaign: international guidelines for management of severe sepsis and septic shock. Intensive Care Med. 2008;34(1):17-60.

19. Rangel-Frausto MS, Pittet D, Costigan M, Hwang T, Davis CS, Wenzel RP. The natural history of the systemic inflammatory response syndrome (SIRS): A prospective study. JAMA. 1995;273(2):117-23.

20. Sprung CL, Sakr Y, Vincent JL, Le Gall JR, Reinhart K, Ranieri VM, et al. An evaluation of systemic inflammatory response syndrome signs in the Sepsis Occurrence in Acutely III Patients (SOAP) study. Intensive Care Med. 2006;32(3):421-7.

21. Bone RC, Balk RA, Cerra FB, Dellinger RP, Fein AM, Knaus WA, et al. Definitions for sepsis and organ failure and guidelines for the use of innovative therapies in sepsis. The ACCP/SCCM Consensus Conference Committee. American College of Chest Physicians/ Society of Critical Care Medicine. Chest. 1992;101(6):1644-55.

22. Azevedo JR, Araujo LO, da Silva WS, Azevedo RP. A carbohydraterestrictive strategy is safer and as efficient as intensive insulin therapy in critically ill patients. J Crit Care. 2010;25(1):84-9.

23. Ranieri VM, Thompson BT, Barie PS, Dhainaut JF, Douglas IS, Finfer $S$, et al. Drotrecogin alfa (activated) in adults with septic shock. Vangerow B, Williams MD; PROWESS-SHOCK Study Group. Drotecogin alfa (activated) in adults with septic shock. N Engl J Med. 2012;366(22):2055-64.

24. Ferreira FL, Bota DP, Bross A, Mélot C, Vincent JL. Serial evaluation of the SOFA score to predict outcome in critically ill patients. JAMA. 2001;286(14):1754-8

25. Jones AE, Trzeciak S, Kline JA. The Sequential Organ Failure Assessment score for predicting outcome in patients with severe sepsis and evidence of hypoperfusion at the time of emergency department presentation. Crit Care Med. 2009;37(5):1649-54.

26. Suberviola B, Castellanos-Ortega A, González-Castro A, GarcíaAstudillo LA, Fernández-Miret B. Prognostic value of procalcitonin, C-reactive protein and leukocytes in septic shock. Med Intensiva. 2012;36(3):177-184.

Received on 10/05/2012

Accepted for publication 12/07/2012

Conflict of interest: none

Source of funding: none

\section{How to cite this article:}

Azevedo JRA, Torres OJM, Czeczko NG, Tuon FF, Nassif PAN, Souza GD. Procalcitonin as a prognostic biomarker of severe sepsis and septic shock. Rev Col Bras Cir. [periódico na Internet] 2012; 39(6). Disponível em URL: http://www.scielo.br/rcbc

\section{Adress for correspondence:}

Orlando Jorge Martins Torres

E-mail: o.torres@uol.com.br 